\title{
Morphogenic Variability of Some Autochthonous Plum Cultivars in Western Serbia
}

\author{
Tomo Milosevic $^{1 *}$, Nebojsa Milosevic ${ }^{2}$ and Evica Mratinic $^{3}$ \\ ${ }^{1}$ Faculty of Agronomy; Department of Fruit Growing and Viticulture; Cara Dusana 34; 32000; Cacak - Serbia. \\ ${ }^{2}$ Fruit Research Institute; Department of Pomology and Fruit Breeding; Kralja Petra I/9; 32000; Cacak - Serbia. \\ ${ }^{3}$ Faculty of Agriculturae; Department of Fruit Growing; Nemanjina 6; 11000; Belgrade - Serbia
}

\begin{abstract}
A study conducted over a period of two years in a Western Serbian valley included in situ identification of autochthonous plum cultivars. Observation and recording of their phenological and pomological traits were performed using IBPGR and UPOV methodologies. Fifteen cultivars derived from Prunus domestica L. and two cultivars derived from P. insititia L. were identified. Flowering started between 24 March and 7 April and fruit ripening between 12 July (Petrovača) and 16 September (Trnovača). Fruit weight ranged from 6.79 \pm 0.018 to $36.62 \pm 0.251 \mathrm{~g}$ and stone weight from $0.14 \pm 0.002$ to $1.95 \pm 0.023 \mathrm{~g}$. The cultivars were classified as being extremely small in terms of fruit size. Rounded fruit shape and light-yellow ground colour were dominant. Skin colour ranged from amber to black. Yellow green was a dominant flesh colour and medium flesh firmness predominated. The fruits of the above cultivars could be processed, particularly into plum brandy, or they could be used fresh or dried. The selected plum cultivars can be used both in breeding programmes and as rootstocks as well as in further diseaserelated systematic studies under field and laboratory conditions.
\end{abstract}

Key words: Fruit, genetic bases, germplasm, Prunus domestica L., Prunus insititia L.

\section{INTRODUCTION}

In terms of total plum production, Serbia ranks fourth worldwide (Milosevic et al., 2008). The Serbian plum production is characterized by extensive growing technology, low unstable yields, low-quality fruit, PPV-induced problems and a multitude of cultivars. The cultivars include Pozegaca (35\%), foreign standard and Serbian newly bred cultivars $(15 \%)$ and autochthonous (local, primitive) cultivars $(50 \%)$, their fruits being generally used for brandy production (Mratinic, 2000). Autochthonous plum cultivars are a limiting factor in improving plum production in Serbia. Nevertheless, they are used as an outstanding source of germplasm and as a genetic basis underlying breeding activities, principally the development of new cultivars, clonal selection (Ogasanovic et al., 1994; Milosevic, 2000), the development of new plum, apricot and peach rootstocks (Paunovic, 1988; Djuric et al., 1998), resistance to economically important diseases (Paunovic and Paunovic, 1994; Rodrigues et al., 2009) or intensive cultivation (Mratinic, 2000). Similar investigations focusing on identical or similar objectives were also conducted in the other countries of the former Yugoslavia - Montenegro (Jovancevic, 1977), Bosnia and Herzegovina (Jarebica and Muratović, 1977; Buljko, 1977), Croatia (Jelacic et al., 2008) and Slovenia (Usenik et al., 2007).

\footnotetext{
*Author for correspondence: tomom@tfc.kg.ac.rs
} 
In situ investigations of cultivars derived from Prunus domestica L. and P. insititia L. in Serbia were conducted by a number of researchers (Paunovic et al., 1985; Paunovic, 1988; Paunovic and Paunovic, 1994; Petrovic et al., 2002) who defined important biological, pomological and technological traits of both fruit and tree. They reported that the selected cultivars could be used both in breeding programmes and as rootstocks, as well as in further disease-related systematic studies under field and laboratory conditions.

The main objective of this study was to determine in situ basic biological and pomological traits of some autochthonous plum cultivars derived from $P$. domestica L. and $P$. insititia L. in Western Serbia that could be used as a genetic basis and source of germplasm for future breeding studies.

\section{MATERIALS AND METHODS}

Investigations were conducted in 2007 and 2008. They involved in situ identification, marking and observation of autochthonous plum cultivars (accessions) in a valley in Western Serbia. Seventeen genotypes or cultivars, derived from $P$. domestica L., except for cvs. Trnovača and Turgulja originating from $P$. insititia L., were selected (Paunovic et al., 1985). The sampled trees were aged 42 (Cerovački Piskavac) to 79 years (Marićevka). The trees of all the cultivars grew on their own roots.

The study focused on two segments. The first one included recording of the phenological traits - first flowering, full flowering, end of flowering and harvest date. Phenological characteristics were determined as below: the beginning of flowering was recorded when at least $5 \%$ of the flowers bloomed; full flowering was accepted when at least $80 \%$ of the flowers bloomed, the end of flowering was determined when $90 \%$ of the flowers bloomed and corollas began to fall off, and harvest date was established when the fruits were sufficiently coloured and soft to be eaten (Funt, 1998). The other segment comprised pomological, i.e. physical [fruit weight $(\mathrm{g})$, stone weight $(\mathrm{g})$ and fruit size (on a scale of 1-9)] and sensorial traits of the fruit [fruit shape (1-6), ground colour (1-5), skin colour (0-9), flesh colour (1-9), flesh firmness (1-9) and fruit usage (1-4)]. IBPGR and UPOV methodologies were used to describe the cultivars in phenological, pomological and sensorial terms (Zanetto et al., 2002). Measurements included the weight of 25 fruits and as much stones per cultivar. Fruit and stone weights were determined using a Tehnica ET-1111 technical scale (range of measurement 0.01-120.00 g, precision $\pm 0.01 \mathrm{~g}$ ).

Data were averaged over the two growing seasons and then subjected to statistical analysis performed using the SAS (SAS Institute, 2002).

\section{RESULTS AND DISCUSSION}

The phenological characteristics of autochthonous (local, primitive) plum cultivars are given in Table 1. The data showed that the onset of flowering was recorded in the last ten days of March and in the first ten days of April. The earliest onset of flowering was observed in cv. Trnovača (24.03) derived from $P$. insititia $\mathrm{L}$., and the latest in cv. Bela Požegača (White Pozegaca in English) and Požegača (7.04) originating from $P$. domestica $L$. Among the 17 cultivars examined, nine (52.94\%) started to flower at the end of March, and eight $(47.06 \%)$ during the middle of the first ten-day period of April. The full flowering stage lasted from 28 March (Trnovača) to 13 April (Bela Požegača and Požegača), and the end of flowering from 5 April (Trnovača) to 19 April (Bela Požegača and Požegača). Flowering lasted 8 (Marićevka) to 14 days (Belošljiva, Crvena Ranka var. Derosavka, Čokešinka and Petrovača). The harvest period was longer than the flowering period (Gunes, 2003), as it lasted from 12 July (Petrovača) to 16 September (Trnovača). Local plum cultivars began to flower at the end of March or at the beginning of April under the environmental conditions of Serbia (Paunovic, 1988; Paunovic and Paunovic, 1994; Mratinic, 2000; Milosevic, 2000). Similar data on the period and duration of flowering of autochthonous plum cultivars were reported by Jovancevic (1977) and Jarebica and Muratovic (1977) and confirmed by the results of this study. Somewhat later flowering under Slovenian conditions was reported by Usenik et al. (2007) and early flowering in the Tokat province (Turkey) by Gunes (2003), the reason being environmental, particularly climate effects (Buljko, 1977). In terms of fruit ripening, the results of this study were identical to the ones obtained by Paunovic et al. (1985), Paunovic (1988) and Mratinic (2000).

Measurable pomological characteristics of fruit and stone are given in Table 2. Fruit weight ranged 
from $6.79 \pm 0.018 \mathrm{~g}$ (Trnovača) to $36.62 \pm 0.251 \mathrm{~g}$ (Mudara). It was above $20.00 \mathrm{~g}$ in cvs. Bela Požegača, Crvena Ranka var. Bardaklija, Požegača and Turgulja, and above $30.00 \mathrm{~g}$ in Mudara, as opposed to the fruit weight of the other cultivars being below $20.00 \mathrm{~g}$. Jarebica and Muratovic (1977) determined that the plum fruit weight ranged from 14.17 to $41.70 \mathrm{~g}$. Jovancevic (1977) reported minimum and maximum values of fruit weights of some local plum cultivars, being 5.03 and $23.86 \mathrm{~g}$, respectively. In the study conducted by Petrovic et al. (2002), fruit weight of eight local plum cultivars in Eastern Serbia and in the region of Cacak (Western Serbia) ranged from 15.20$26.40 \mathrm{~g}$ and from 6.68-36.50 $\mathrm{g}$, respectively (Paunovic et al., 1985). According to Mratinic (2000), fruit weight of autochthonous plum cultivars in a broader region of south-western
Serbia and Sumadija fell within a range of 6.20$28.00 \mathrm{~g}$ with $50 \%$ of the cultivars having the fruit weight of $15.00 \mathrm{~g}$. Similar data for autochthonous plum cultivars were reported by researchers from other countries. In Turkey, for example, Gunes (2003) reported the fruit weight of local plum cultivars in the Tokat province to range from 5.23$25.18 \mathrm{~g}$ and from $8.30-29.50 \mathrm{~g}$ in the Van province. The results obtained in this study confirmed those provided by the above authors in terms of the high degree of genotypic variability in fruit weight of autochthonous (local) plum cultivars. The cultivars selected in this study were classified as being extremely small in terms of fruit size, whereas the fruits of cv. Mudara were the only ones classified as being very small (Paunovic et al., 1985; Mratinic, 2000; Zanetto et al. 2002).

Table 1 - Phenological characteristics of autochthonous plum cultivars in Western Serbia.

\begin{tabular}{|c|c|c|c|c|c|}
\hline \multirow{2}{*}{$\begin{array}{l}\text { Cultivar } \\
\text { (Local name) }\end{array}$} & \multicolumn{4}{|c|}{ Flowering } & \multirow{2}{*}{$\begin{array}{c}\text { Harves } \\
\text { date }\end{array}$} \\
\hline & Onset & Full & End & Duration (days) & \\
\hline Arapka & 4.04 & 8.04 & 13.04 & 9 & 17.08 \\
\hline Bela Požegaca & 7.04 & 13.04 & 19.04 & 12 & 11.09 \\
\hline Belošljiva & 28.03 & 1.04 & 11.04 & 14 & 5.08 \\
\hline Cerovački Piskavac & 3.04 & 7.04 & 13.04 & 10 & 14.08 \\
\hline Crnošljiva & 29.03 & 2.04 & 11.04 & 13 & 8.08 \\
\hline Crvena Ranka* & 28.03 & 2.04 & 10.04 & 13 & 4.08 \\
\hline Crvena Ranka** & 27.03 & 1.04 & 10.04 & 14 & 4.08 \\
\hline Čokešinka & 28.03 & 1.04 & 11.04 & 14 & 13.08 \\
\hline Kapavac & 3.04 & 6.04 & 12.04 & 9 & 29.07 \\
\hline Marićevka & 3.04 & 6.04 & 11.04 & 8 & 10.08 \\
\hline Metlaš & 30.03 & 4.04 & 10.04 & 11 & 11.08 \\
\hline Mudara & 31.03 & 5.04 & 12.04 & 12 & 6.08 \\
\hline Obični Piskavac & 4.04 & 7.04 & 14.04 & 10 & 20.08 \\
\hline Petrovača & 26.03 & 30.03 & 9.04 & 14 & 12.07 \\
\hline Požegača & 7.04 & 13.04 & 19.04 & 12 & 6.09 \\
\hline Trnovača & 24.03 & 28.03 & 5.04 & 12 & 16.09 \\
\hline Turgulja & 2.04 & 6.04 & 11.04 & 9 & 21.08 \\
\hline
\end{tabular}

* Crvena Ranka var. Bardaklija; ** Crvena Ranka var. Derosavka

The most dominant fruit shape was rounded - in eight cultivars, followed by elliptical - in five cultivars, oblong - in 2 cultivars and ovate - in two cultivars (Paunovic and Paunovic, 1994). Ground colour in most of the cultivars was light yellow (8) and light green (8), being green only in cv. Trnovača. Skin colour ranged from amber (1) and black (1), to blue (2), dark violet (2), white yellow (2), red violet (4) to dark blue (5 cultivars). Flesh colour was yellow green in most cultivars, and light green only in cvs. Cerovački Piskavac and
Trnovača. As for flesh firmness, it was medium in 10 cultivars, firm in five and soft in two cultivars. The fruits of all the cultivars could be used for different types of processing, particularly for plum brandy production (Joshi and Sandhu, 2000). The fruits of Bela Požegača, Crvena Ranka var. Bardaklija and Požegača can be used fresh, and those of Požegača can also be dried (Mratinic, 2000). Similar data for Serbian autochthonous plum cultivars in terms of pomological, physical and sensorial characteristics were reported by 
Paunovic et al. (1985), Paunovic (1988) and Petrovic et al. (2002), and data on local cultivars grown in the former Yugoslavia were given by Jovancevic (1977), Jarebica and Muratovic (1977), Usenik et al. (2007), Jelacic et al. (2008).

Stone weight ranged from $0.14 \pm 0.002 \mathrm{~g}$ (Trnovača) to $1.95 \pm 0.023 \mathrm{~g}$ (Mudara), which was in agreement with the results obtained by Paunovic et al. (1985), Paunovic (1988), Paunovic and Paunovic (1994) and Mratinic (2000).

The obtained values, particularly those for fruit weight and fruit size, were lower than the ones reported for standard commercial cultivars, both foreign and domestic ones. The fact that substantial climate- and soil-dependent variations could occur in the above traits should be taken into account. Importantly, some cultivars are found to be promising in terms of fruit traits. Almost all the fruits can be processed, particularly into plum brandy, or used fresh (Bela Požegača, Crvena Ranka var. Bardaklija, Mudara and Požegača) and dried (Požegača). More importantly, the autochthonous (primitive, local) cultivars or accessions observed in this study can be used as an outstanding genetic basis and source of germplasm in plum breeding aimed at developing new cultivars and rootstocks (Djuric et al., 1998; Esmenjaud and Dirlewanger, 2007).

However, since the results obtained in this study are only preliminary, reliable estimation will be possible only through a multi-disciplinary approach to examining selected cultivars grown in a collection orchard as well as through further findings to be attained under field and laboratory conditions over the next five to ten years.

Table 2 - Pomological and sensorial characteristics of autochthonous plum cultivars in Western Serbia ${ }^{\dagger}$

\begin{tabular}{|c|c|c|c|c|c|c|c|c|c|}
\hline $\begin{array}{l}\text { Cultivar } \\
\text { (Local name) }\end{array}$ & $\begin{array}{c}\text { Fruit } \\
\text { weight (g) }\end{array}$ & $\begin{array}{l}\text { Fruit } \\
\text { size }^{1}\end{array}$ & $\begin{array}{c}\text { Fruit } \\
\text { shape }^{2}\end{array}$ & $\begin{array}{l}\text { Ground } \\
\text { colour }^{3}\end{array}$ & $\begin{array}{c}\text { Skin } \\
\text { colour }\end{array}$ & $\begin{array}{c}\text { Flesh } \\
\text { colour }^{5}\end{array}$ & $\begin{array}{c}\text { Flesh } \\
\text { firmness }^{6}\end{array}$ & $\mathbf{U s e}^{7}$ & $\begin{array}{c}\text { Stone } \\
\text { weight }(\mathrm{g})\end{array}$ \\
\hline Arapka & $16.34 \pm 0.098$ & 1 & 6 & 2 & 7 & 3 & 3 & 2 & $0.67 \pm 0.141$ \\
\hline Bela Požegača & $22.60 \pm 0.403$ & 1 & 6 & 3 & 0 & 3 & 7 & 1,2 & $0.56 \pm 0.003$ \\
\hline Belošljiva & $14.00 \pm 0.200$ & 1 & 2 & 3 & 0 & 3 & 3 & 2 & $0.93 \pm 0.019$ \\
\hline Cerovački Piskavac & $19.81 \pm 0.237$ & 1 & 3 & 3 & 5 & 2 & 5 & 2 & $0.38 \pm 0.003$ \\
\hline Crnošljiva & $13.78 \pm 0.267$ & 1 & 3 & 2 & 7 & 3 & 7 & 2 & $0.56 \pm 0.011$ \\
\hline Crvena Ranka* & $22.79 \pm 0.266$ & 1 & 4 & 3 & 3 & 3 & 5 & 1,2 & $0.76 \pm 0.004$ \\
\hline Crvena Ranka** & $17.50 \pm 0.051$ & 1 & 4 & 3 & 3 & 3 & 5 & 2 & $0.56 \pm 0.003$ \\
\hline Čokešinka & $19.66 \pm 0.098$ & 1 & 3 & 3 & 7 & 3 & 5 & 2 & $0.74 \pm 0.003$ \\
\hline Kapavac & $11.11 \pm 0.064$ & 1 & 3 & 2 & 8 & 3 & 5 & 2 & $0.43 \pm 0.002$ \\
\hline Marićevka & $15.81 \pm 0.038$ & 1 & 2 & 2 & 6 & 3 & 5 & 2 & $0.83 \pm 0.006$ \\
\hline Metlaš & $17.36 \pm 0.051$ & 1 & 2 & 3 & 3 & 3 & 7 & 2 & $0.66 \pm 0.004$ \\
\hline Mudara & $36.62 \pm 0.251$ & 2 & 2 & 3 & 3 & 2 & 5 & 2 & $1.95 \pm 0.023$ \\
\hline Obični Piskavac & $14.39 \pm 0.034$ & 1 & 2 & 2 & 6 & 3 & 5 & 2 & $0.62 \pm 0.003$ \\
\hline Petrovača & $12.10 \pm 0.084$ & 1 & 2 & 2 & 5 & 3 & 5 & 2 & $1.12 \pm 0.028$ \\
\hline Požegača & $23.45 \pm 0.200$ & 1 & 3 & 2 & 7 & 3 & 7 & $1,2,4$ & $0.67 \pm 0.002$ \\
\hline Trnovača & $6.79 \pm 0.018$ & 1 & 2 & 1 & 7 & 2 & 7 & 2 & $0.14 \pm 0.002$ \\
\hline Turgulja & $20.91 \pm 0.221$ & 1 & 2 & 2 & 9 & 3 & 5 & 2 & $1.56 \pm 0.011$ \\
\hline \multicolumn{10}{|c|}{$\begin{array}{l}{ }^{7} \text { IBPGR and UPOV Descriptor List for Plum (Zanetto et al., 2002); } \\
* \text { Crvena Ranka var. Bardaklija; ** Crvena Ranka var. Derosavka; } \\
{ }^{1} \text { Fruit size: } 1=\text { extremely small, } 2=\text { very small; } \\
{ }^{2} \text { Fruit shape: } 2=\text { rounded, } 3=\text { elliptical, } 4=\text { ovate, } 6=\text { oblong; } \\
{ }^{3} \text { Ground colour: } 1=\text { green, } 2=\text { light green, } 3=\text { light yellow; } \\
{ }^{4} \text { Skin colour: } 0=\text { white yellow, } 3=\text { red violet, } 5=\text { dark violet, } 6=\text { blue, } 7 \text { = dark blue, } 8=\text { black, } 9=\text { amber; } \\
5 \text { Flesh colour: } 2=\text { light green, } 3=\text { yellow green; } \\
{ }^{6} \text { Flesh firmness: } 3=\text { soft, } 5=\text { medium, } 7=\text { firm; } \\
{ }^{7} \text { Use: } 1=\text { fresh, } 2=\text { processing, } 4=\text { other (drying) }\end{array}$} \\
\hline
\end{tabular}

\section{CONCLUSIONS}

The onset of flowering of the autochthonous plum cultivars derived from $P$. domestica $\mathrm{L}$. and $P$. insititia L. lasted from the middle of the last tenday period in March to the middle of the first tenday period in April. The cultivars flowered from the beginning of the second ten-day period in July to the end of the second ten-day period in September. The fruits were extremely small. Rounded shape, yellow-green ground colour and yellow-green flesh colour predominated. All the fruits could be processed, and some could be dried or used fresh. The autochthonous (primitive, local) 
plum cultivars or accessions observed in this study could serve as an outstanding genetic basis and a source of germplasm for plum breeding aimed at developing new cultivars and rootstocks.

\section{ACKNOWLEDGEMENTS}

Authors give special thanks to Ms. Jelena Krstic, Faculty of Agronomy, Cacak, for translating the paper into English.

\section{REFERENCES}

Buljko, M. (1977), Some characteristics of the Japanese variety Florentia (Prunus triflora) grown in ecological conditions of Herzegovina. Acta Hort., 74, 137-142.

Djuric, G.; Micic, N. and Lucic, P. (1998), Growth and bearing potential of plum cultivars Stanley and Pozegaca on the two stock/interstock combinations and on Myrobalan. Acta Hort., 478, 225-228.

Esmenjaud, D. and Dirlewanger, E. (2007), Genome Mapping and Molecular Breeding in Plants. In-Fruits and Nuts - Plum, ed. C. Kole. Springer, Netherland, pp. 119-135.

Funt, R.C. (1998), Plums: A guide to selection and use. Ohio State University Extension Fact Sheet.

Gunes, M. (2003), Some local plum varieties grown in Tokat province. Pakistan J. Appl. Sci., 3, 291-295.

Jarebica, S.D. and Muratovic, S.A. (1977), Some properties of growth and productivity of plum cultivars in Bosnia. Acta Hort., 74, 125-127.

Jelacic, T.; Dermic, E.; Halapija-Kazija, D.; Vujevic, P.; Savic, Z.; Bisko, A. and Cvjetkovic, B. (2008), Analysis of autochthonous plum cultivars (Prunus domestica L.) in Croatia for the presence of Plum Pox Virus. J. Plant Pathol., 90, 3-7.

Jovancevic, R. (1977), Biological and economic properties of some outstanding prune cultivars grown in the River Valley. Acta Hort., 74, 129-136.

Joshi, K.V. and Sandhu, K.D. (2000), Influence of ethanol concentration, addition of spices extract, and level of sweetness on physico-chemical characteristics and sensory quality of apple vermouth. Braz. Arch. Biol. Technol., 43, 537-545.

Milosevic, T. (2000), Bearing potential of standard and selected Pozegaca. Acta Hort., 536, 369-373.
Milosevic, T.; Zornic, B. and Glisic, I. (2008), A comparison of low-density and high-density plum plantings for differences in establishment and management costs, and in returns over the first three growing seasons. J. Hort. Sci. and Biotech., 83, 539542.

Mratinic, E. (2000), The selection of the autochthonous plum cultivars suitable for intensive growing. In- $1^{\text {st }}$ International scientific symposium: production, processing and marketing of plums and plum products, Kostunici, Serbia. Proceedings, 1, 193-196.

Ogasanovic, D.; Rankovic, M.; Plazinic, R. and Papic, V. (1994), Performance of newly-bred Cacak plum cultivars and current breeding tendencies. Acta Hort., 359, 75-81.

Paunovic, A.S. (1988), Plum cultivars and their improvements in Yugoslavia. Fruit Variet. J., 42, 143-151.

Paunovic, S.; Stankovic, D.; Madzarevic, P.; Milosevic, T.; Kojovic, R. and Popovic, D. (1985), The plum cultivars in Yugoslavia. Exploration, collecting, conservation and exchange of hexaploid species of Prunus domestica L. and Prunus insititia L. in Yugoslavia. Faculty of Agronomy, Cacak, Serbia, pp. $1-212$.

Paunovic, S.A. and Paunovic, A.S. (1994), Investigations of plum and prune cultivars (Prunus domestica L. and Prunus insititia L.) in situ in SFR Yugoslavia. Acta Hort., 359, 49-54.

Petrovic, R.; Miletic, R. and Mitrovic, M. (2002), Some biological characteristics of introduced plum cultivars. Acta Hort., 577, 239-243.

Rodrigues, P.S.; Lindsey, G.G. and Fernandes, B.M.P. (2009), Biotechnological approaches for plant viruses resistance: From general to the modern RNA silencing pathway. Braz. Arch. Biol. Technol., 52, 795-808.

SAS Institute (2002), Getting started with the SAS learning edition. Cary: SAS, p. 200.

Usenik, V.; Stampar, F. and Fajt, N. (2007), Pomological and phonological characteristics of some plum cultivars. Acta Hort., 734, 53-59.

Zanetto, A.; Maggoni, L., Tobutt, R.K. and Dosba, F. (2002), Prunus genetic resources in Europe: Achievement and perspectives of a networking activity. Genet. Resour. Crop Ev., 49, 331-337. 